European Association for the

Development of Renewable Energies,

Environment and Power Quality (EA4EPQ)
International Conference on Renewable Energies and Power Quality

(ICREPQ'11)

Las Palmas de Gran Canaria (Spain), 13th to 15th April, 2011

\title{
Economic Viability of Bamboo Dust Based Gasification Plant for a Paper Mill
}

\author{
Dr. A. K. Sinha ${ }^{1}$, MeghnaBarkakat ${ }^{1}$, Dibakar Nath ${ }^{1}$, Saurav Kumar Sarma ${ }^{1}$, \\ Uday Reddy ${ }^{1}$, Abhinav Verma ${ }^{1}$, Kranthi Kiran $\mathrm{Ch}^{1}$ \\ ${ }^{1}$ Department of Electrical Engineering \\ National Institute of Technology Silchar \\ Assam. Pin: 788010 \\ INDIA \\ E-mail: ashokesinha2001@yahoo.co.in,kranthi.kiran213@gmail.com
}

\begin{abstract}
Global concern over pollution and several related issues caused by increase in Green House Gas emission and consequently changes in climate have resulted in a paradigm shift in the approach towards development of the energy sector in many countries. Being relatively less expensive than other renewable sources like solar and wind energy and being geographically dispersed, biomass is a potential alternative for fossil fuels like coal to sustainably meet the increasing energy needs of the world. In addition to this, biomass is carbon dioxide neutral and is a reliable source of energy.

In this paper a pilot project is conceptualized on the use of bamboo dust waste for Cachar Paper Mill located in the state of Assam, India. This paper mill is a source of biomass in itself as it generates about 35-40 tons of bamboo dust every day. This project is conceived to economically generate electricity by utilizing producer gas derived from a gasifier by means of a gas engine coupled with an alternator, thus contributing its share towards renewable energy in the country. An economic viability study has been carried out by calculating the cost of generation of electricity for the plant to produce this green energy as against that of convention coal fired stream generation. This paper further highlights how burning of reasonable quantity of coal can be avoided by replacing some quantum of electricity generation through renewable energy sources resulting in appreciable amount of cost savings.
\end{abstract}

\section{Key Words}

Biomass gasification, producer gas engine, renewable energy, paper mill.

\section{Introduction}

Nature's endowments in the form of natural resources are used by human beings for their sustenance. Conventional sources of energy based on oil, coal and natural gas are used extensively for generation of electricity worldwide. However over exploitation due to ever increasing energy demands of these resources, will lead to scarcity and ultimately result in exhaustion. The dwindling coal reserve of the planet is a living proof in support of this fact. To ensure stable long term supply of electrical energy in the future, the use of alternative non conventional or renewable sources of energy is only solution. Being $\mathrm{CO}_{2}$ - neutral, they also help in reducing the effect of the green house gases.

Renewable sources of energy like solar and wind energy are characterized by high investment cost and seasonal and site dependency. The total energy stored in terrestrial biomass outnumbers the annual world energy consumption by a factor of more than fifty. Biomass is easily available and a relatively cheaper technology to install for generation of decentralized electricity. Worldwide, biomass-to-electricity generation has gained importance due to employment opportunity, reduction in reliance on fossil fuels and positive environmental benefits.

Biomass is a source of energy in the form of crops, seaweed, animal waste, wood or any other organic matter [1]. It is one of the oldest forms of energy used by man and is renewable. It derives its source of energy from the Sun and converts the radiant solar energy into chemical form of carbohydrates or sugars through a process of photosynthesis.

\section{A. Rationale:-}

There are a number of reasons [2] why biomass is an attractive feedstock for electricity generation.

1) Environmentally biomass has several advantages over fossil fuels like coal and petroleum. It contains lesser amounts of nitrogen and sulphur as compared to fossil fuels thus not contributing towards the formation of acid rain. As plants grow, they utilise $\mathrm{CO}_{2}$ present in the atmosphere, keeping the levels of carbon dioxide balanced.

2) Since any biomass material can undergo gasification, this process is much more attractive than ethanol production or biogas where only selected biomass materials can produce the fuel.

3) Economic factors also support gasification as it uses bamboo dust waste produced in the mill and 
additional cost of purchasing fossil fuel and transportation cost is absent in this case.

\section{Theory}

Biomass is a natural substance available, which stores solar energy by the process of photosynthesis in the presence of sunlight and with the help of chlorophyll. It chiefly contains cellulose, hemi cellulose and lignin, with an average composition of $\mathrm{C}_{6} \mathrm{H}_{10} \mathrm{O}_{5}$, with slight variations depending on nature of the biomass. Theoretically, the ratio of air-to-fuel required for complete combustion of the biomass, defined as stoichiometric combustion is $6: 1$ to $6.5: 1$, with the end products being $\mathrm{CO}_{2}$ and $\mathrm{H}_{2} \mathrm{O}$. In gasification the combustion is carried at sub-stoichiometric conditions with air-to-fuel ratio being $1: 5: 1$ to $1: 8: 1$. The gas so obtained is called producer gas, which is combustible.

This process is made possible in a device called gasifier, in a limited supply of air. A gasifier system is basically comprises of a reactor, where the gas is generated, and is followed by a cooling and cleaning system, which cools and cleans the gas. The clean combustible gas is thus available for power generation application.

In the reactor biomass pieces after undergoing drying and devolatisation in the upper zones, leave behind the char. The volatiles undergo oxidation in the combustion zone. With air being partially supplied by the surrounding nozzles, and remaining drawn from the open top. The product gases of oxidation further gets reduced by a bed of charcoal and yield a combustible gas having a calorific value of $4.5-5.0 \mathrm{MJ} / \mathrm{kg}$, with an average composition approximately of $\mathrm{CO}=20 \%$ $, \mathrm{CH}_{4}=3 \%, \mathrm{H}_{2}=20 \%, \mathrm{CO}_{2}=12 \%$ and rest is $\mathrm{N}_{2}$.

\section{A. Process Description}

The overall schematic of the gasifier is shown in Fig 1. This is basically an open top downdraft system, where both gas and feedstock move downward as the reaction proceeds. The air required for gasification is partly drawn from the top, and the remaining from the air nozzles surrounding the combustion zone and central air nozzle directed to the reactor core. The required suction for this process is obtained from the gas engine. Bio-residue after drying and pyrolysing in the upper zone of the reactor undergoes volatile combustion becoming char by the time it reaches the oxidation zone. In the oxidation zone the volatiles undergo oxidation with the release of $\mathrm{CO}_{2}$ and $\mathrm{H}_{2} \mathrm{O}$. These product gases undergo reduction, in the presence of hot bed of charcoal, and yield a combustible mixture. The hot gas existing at the reactor bottom passes through cooling and cleaning system consisting of water sprays, scrubbers, blower and fabric filters. Water for the plant can either be used as a single pass or re-circulated by using a water treatment plant.

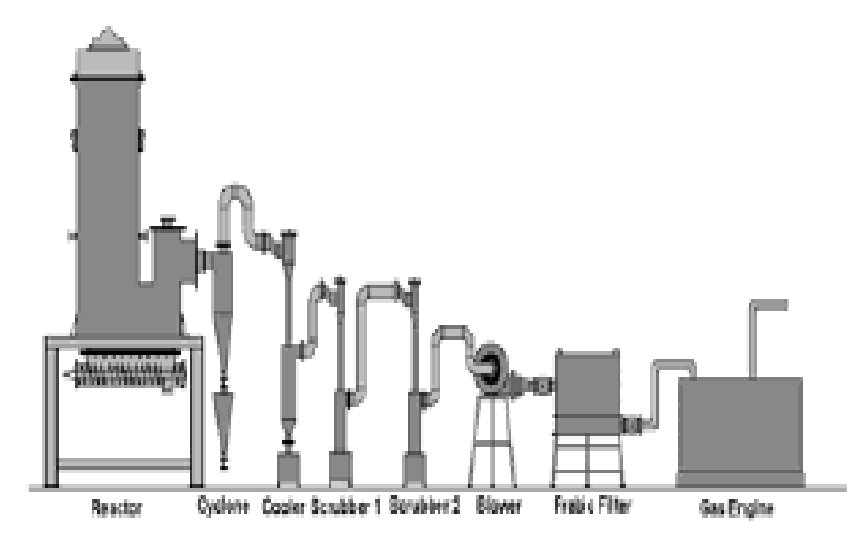

Fig. 1 Process Description

\section{B. Gasification Plant}

The system consists of gasification reactor [3] of appropriate rated capacity of $100 \mathrm{~kg} / \mathrm{hr}$ bamboo dust a scrubbing system for cooling the producer gas to extremely high quality rendering it suitable for end use operation and necessary ducting to the burner. This system is also designed to accept a wide variety of properly sized solid bio-residues such as cut bamboo pieces, briquetted bamboo waste, chopped coconut fronds, coconut husk, corn cobs, mulberry stocks, cotton stalks, weeds like prosopsis juliflora, Ipomoea with a moisture content around $15 \%$ of briquettes from agro residue such as sawdust, sugarcane trash etc. of known composition. Typical consumption of biomass for replacing 1lite furnace oil would $\mathrm{b} 3.5+0.5 \mathrm{~kg}$, depending on the ash and moisture content of the biomass. The gasification plant is engineered incorporating all the necessary safety features for long-term reliable performance, with minimum down time for maintenance. The gasification plant incorporates the following sub systems.

\section{1) Reactor:}

The reactor is cylindrical vessel made of mild steel, with an inner lining of cold face insulation bricks, hot face insulation bricks and ceramic tiles composed of largely alumina. Air nozzles, provided around the composition zone, are kept open during the running of the system. To allow for uniform availability across the reacting bed, an additional nozzle called the central nozzle is directed to the reactor core. A water seal with removable cover forms the top of the reactor, which is kept open during the entire operation of the system, to facilitate primary air induction and loading of feedback. A motorized ash extraction system is provided at the reactor bottom to hold the char or ash as the case may be a mechanism for intermittent extraction of cha/ash. 


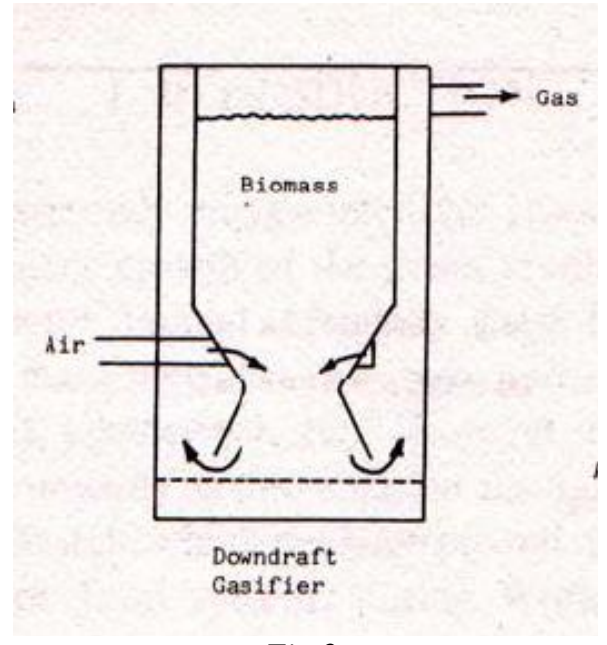

Fig 2.

\section{2) Hot Cyclone:}

The hot gas exciting the reactor passes through a cyclone where the particulates are stripped off from the gas due to centrifugal separation. The gas beyond this goes to cooling and scrubbing systems.

\section{3) Gas Cooling System:}

It consists of a direct water important cooler, which is meant for cooling the hot gases to ambient for engine applications and scrubbing the gas to remove the entrained tar and particulate matter. When the gasifier system is operated at the rated load, the system requires $180 \mathrm{~m} 3 / \mathrm{hr}$ of waste on a continuous basis. The coolers perform the twin functions of cooling and cleaning the producer gas.

\section{4) Gas Filtering System:}

This sub system consists of chilled water scrubber. The purpose of the filtering system is reduce the quality of tar, particulate matter and moisture in the gas to levels that are acceptable for direct admission into gas burners.

\section{5) Instrumentation and Control:}

Temperature, pressure, tar, particulate and oxygen content in the gas are used to monitor the health of the gasifier system. The following instrumentation is mandatory for regular operation of the system. Any additional instrumentation adds to the operational convenience.

\section{6) Gas Engine:}

Using producer gas it is possible to operate a diesel engine on dual fuel mode with marginal changes to the air inlet or a gas alone engine. Diesel substitution of the order of 80 to $85 \%$ can be obtained at nominal loads in the dual fuel mode. The recent developments have made possible the operations of Spark ignited gas engine using producer gas alone. The mechanical energy thus derived can be used either for energizing a water pump set for irrigational purpose or by coupling with an alternator for electrical power generation, either for local consumption or for grid synchronization. It is proposed to use
$500 \mathrm{KW}$ gas engine normally available in the market (CUMMINS) to generate electricity coupled with an alternator $(500 \mathrm{KW})$ by using the producer gas.

\section{Case Study}

The plant selected is the Cachar Paper Mill (CPM) a unit of Hindustan Paper Co-operation Ltd (HPC) located in Panchgram in Assam, India. It uses almost 2, 00,000 BDMT of bamboo annually for the production of 1,00,000 MT of paper. It is estimated that the mill generates almost 35-40 MT of bamboo dust every day and it pays a considerable amount to dispose this waste daily. The Pilot Generation Project has now been conceptualized to economically generate electricity by utilizing producer gas derived from the gasifier which generates combustible gas with a calorific value in the range of 4500-5000 from the bamboo dust. Stock piling of the waste occupying huge space in the industrial area can now be avoided making it free from air pollution from environmental angle.

\section{Viability Study}

A. Coal fired generation:

\section{1) Boilers and Steam Generators:}

There are total 3 Boilers with one Waste Heat Recovery Boiler for generation of Steam which is required for the process industry and Electricity generation. 50 ton/hour at pressure of $60 \mathrm{~kg}$ per $\mathrm{cm}^{2}$ at $400^{\circ} \mathrm{C}$ Steam is produced for various applications.7-7.2 MT of steam is produced per MT of coal. Gross calorific value of coal is in the range $6200-6500$ $\mathrm{Kcal} / \mathrm{kg}$ and heat value (UHV) is in the range $5800-6000$ $\mathrm{Kcal} / \mathrm{kg}$ Range Though normal power is produced for $1 \mathrm{MW}$ by 4 MT steam at $60 \mathrm{~kg} / \mathrm{cm}^{2}$ at $400{ }^{\circ} \mathrm{C}$ here because of steam withdrawal for various applications the actual steam required for $1 \mathrm{MW}$ is in the range of 7.5-8.4 MT of steam for $1 \mathrm{MW}$. We can assume 7 MT of steam is produced per MT of coal. We shall however consider a Thumb Rule of 7.5 MT of coal produces $7 \mathrm{MW}$ of power.

2) Price of Coal:

Table 1.

\begin{tabular}{|c|c|}
\hline TYPE & PRICE \\
\hline NEC coal & Rs.3900/MT \\
\hline Nagaland coal & Rs.5200/MT \\
\hline Nangal coal & Rs.5500/MT \\
\hline Meghalaya coal & Rs.4400/MT \\
\hline
\end{tabular}


The price of coal is an average of the different types of coal acquired from various regions and is taken as Rs. 4321/MT.

3) Generation Cost:

In accordance with the data supplied the cost of generation of electricity for the financial year was 2009-10 Rs. 2.95/unit.

Table 2.

\begin{tabular}{|c|c|}
\hline PARTICULARS & VALUE \\
\hline $\begin{array}{c}\text { Coal requirement per } \\
\text { year(2009-10) }\end{array}$ & $199415 \mathrm{MT}$ \\
\hline $\begin{array}{c}\text { Average cost of coal } \\
\text { Steam produced per } \\
\text { year(2009-10) }\end{array}$ & Rs21/MT \\
\hline $\begin{array}{c}\text { Total electricity generated } \\
\text { in(2009-10) }\end{array}$ & $196.48 \mathrm{MU}$ \\
\hline
\end{tabular}

\section{B. Bamboo Dust Gasification}

It has been estimated that industrial waste - Bamboo Dust 3540 tons per day will be able to generate $2800 \mathrm{~kg} /$ hour at $15^{\circ} \mathrm{C}$ Producer Gas with mean Calorific Value of gas $4.6 \mathrm{MJ} / \mathrm{Kg}$. Considering $45 \%$ efficiency of Gas Engine and $92 \%$ efficiency for alternator, a total $1.5 \mathrm{MW}$ of power can be generated from the above quantity of gas. The estimated cost of installing the plant including civil works and electrical works comes around to a total of Rs. 6 Crores. The estimate is given in Table 3. As this pilot project is conceived on the use of Bamboo dust waste from the Industry, the CDM BenefitRebate for carbon credit about 70 paise per unit generated can be availed from the Government of India Renewable Energy Department incentives/schemes. Stock piling of the waste occupying huge space in the industrial area can now be avoided making it free from air pollution from environmental angle.

Table 3 .

\begin{tabular}{|c|c|}
\hline PARTICULARS & VALUE \\
\hline $\begin{array}{c}\text { Capital cost of gasification } \\
\text { plant }\end{array}$ & Rs. $2.7 \mathrm{Cr}$ \\
\hline $\begin{array}{c}\text { Capital cost of diesel } \\
\text { engines }\end{array}$ & Rs. $3.3 \mathrm{Cr}$ \\
\hline $\begin{array}{c}\text { Total capital cost } \\
\text { regulatory commission tariff } \\
\text { determination and cost per } \\
\text { unit }\end{array}$ & Rs. $6 \mathrm{Cr}$ \\
\hline
\end{tabular}

\section{Cost benefit analysis}

Now we compare the yearly saving on coal generating from the existing plant $1.5 \mathrm{MW}$ or 9824460 Units from the existing plant. Gross Saving of Burning of Coal for this $1.5 \mathrm{MW} /$ day for one year will be about Rs. 4.5 Cr. The savings on coal is given by

Table 4.

\begin{tabular}{|c|c|}
\hline PARTICULARS & ESTIMATE \\
\hline $1 \mathrm{MW} /$ hour generation & $1 \mathrm{MT}$ coal/hour \\
\hline $1.5 \mathrm{MW} /$ hour & $1.5 \mathrm{MT} / \mathrm{hr}$ of Coal \\
\hline Per day coal required & $36 \mathrm{MT}$ \\
\hline $\begin{array}{c}\text { Per year Coal required } \\
\text { (PLF 80\% }=292 \text { days) }\end{array}$ & $10512 \mathrm{MT}$ \\
\hline $\begin{array}{c}\text { Cost of coal @ Rs. 4321 } \\
\text { for 10512 MT }\end{array}$ & Rs. $4.5 \mathrm{Cr}$ \\
\hline
\end{tabular}

The Unit cost of Generation from coal based plant has been found as Rs. $2.95(2009-10)$.

Therefore, total saving due to not generating this much energy (9824460 units) from the coal based plant is Rs. 2.89 Cr. The gross saving amounts to Rs. $7.39 \mathrm{Cr}$. Now we calculate the net savings.

Table 5.

\begin{tabular}{|c|c|}
\hline PARTICULARS & AMOUNT \\
\hline $\begin{array}{c}\text { Net per year saving of } \\
\text { cost }\end{array}$ & $\begin{array}{c}\text { Gross saving - total amount of } \\
\text { electricity production cost of } \\
98244460 \text { units from the pilot } \\
\text { Generation Project }\end{array}$ \\
\hline Net saving of cost & 6.11 Cr (say Rs. 6 Cr) \\
\hline
\end{tabular}

In addition to the above, CDM benefit can be availed which will reduce the cost of generation from the proposed Pilot Project further by 70 paisa as per the prevailing norm.

\section{Conclusions}

Use of bamboo dust manufacturing producer gas is to be utilized in generation of electricity will go a long way in fulfilling the renewable energy obligations of the state/central power utilities. Storage space required for stock piling of the accumulated huge quantity of bamboo dust will no longer be necessary in the paper mill and such space can be used for any other purpose of social corporate responsibilities. The paper manufacturing company becomes more eco friendly. As the pilot project is conceived on the use of bamboo dust waste 
from the industry, the CDM benefit for carbon credit which is 70p per unit can be availed from the Govt. of India Renewable Energy department through incentives and schemes. With this the cost of generation further comes down to 60p per nit which makes this extremely economically viable. Further around 11000 MT coal is saved because this amount would otherwise be used to generate $1.5 \mathrm{MW}$ of electricity. Now this amount is not put into use and this doesn't contribute towards carbon dioxide emission in the environment.

The pilot project aims at providing a green edge to the power generated in the power plant by minimizing a sufficient quantum of coal used in the plant thereby not contributing towards GHGs in the country. If this proposal is adopted by all the paper mills in the country a sufficient amount of electricity generated in them will be green energy thus will keep all environmental concerns in check.

\section{Acknowledgment}

We offer our sincere thankfulness to Mr. R.K. Paul of Cachar Paper Mill whose hand of help made things a lot easier for us.

\section{References}

[1] Mathias Loeser, Miles Alexander Redfern," Overview of Biomass Conversion and Generation Technologies".

[2] G. Petrecca, R. Preto(2009), "Energy efficiency technologies for clean electric power from biomasses: the state of the art and perspectives for the future".

[3] Anil K. Rajvanshi(1986), "Biomass Gasification"

[4] Sinha A.K., etc, "Design and testing of PV Maximum Power Tracking System with Matlab Simulation", IEEE ,TENCON2010, 21-24 November,2010.

[5] Sinha A.K., etc, "Meeting Energy demand with Wind as an Energy Source" ICRE 2011 Jaipur India. 